\title{
The End of the Eternal Return of "Econophoria" in Northeast Asia?: On the Use and Abuse of the Economic Concept of Peace*
}

\author{
MASON RICHEY**
}

This article evaluates the concept of "econophoria" in the context of the contemporary international relations of Northeast Asia. The article begins by discussing the idea's general meaning, some of its theoretical and empirical subtleties (including problems), and how it occupies a special role in studies of Northeast Asian security. The middle section examines the geoeconomics and geo-politics of Northeast Asia through an "econophoric" lens, and then identifies the "Asian Paradox" as a situation that calls into question the region's recent status quo. I conclude by arguing why the "econophoric" program requires transformation over coming decades. Notably I demonstrate that international institutions (especially regional institutions) will be a crucial mechanism for continued stability, development, and peace in Northeast Asia going forward.

Keywords: Econophoria, Asian Paradox, Security Studies, Regional Development, International Institutions

* This work was supported by Hankuk University of Foreign Studies Research Fund of 2016-2017.

** Associate Professor, Hankuk University of Foreign Studies, Seoul, South Korea; E-mail: mrichey@hufs.ac.kr

DOI: 10.16934/isr.17.1.201606.121 


\section{INTRODUCTION}

Northeast Asia is a "rough neighborhood." Historical animosity simmers, the shadow of $20^{\text {th }}$ century wars and dictatorships lingers on all of the region's states, skirmishes occur over disputed maritime and territorial claims, no less than three states possess nuclear weapons, a "rogue" state regularly engages in destabilizing provocation, and the world's only global military superpower ${ }^{1}$ maintains intense efforts to preserve its regional prerogatives in the face of a rising, local revisionist power. Yet peace reigns in Northeast Asia, and has done so for more than six decades. In this regard, the region seems to warrant "econophoria," a term describing economic governance prioritization in which solutions to political and social ills are overwhelmingly sought through economic growth and development (Buzan and Segal 1998, 103).

This idea has its counterpoint, however, which one can sum up with the notion of the "Asian Paradox." This refers to persistent and even increasing strategic mistrust among Northeast Asian states, despite the high levels of economic exchange and interdependence. As history moves forward and the $21^{\text {st }}$ century enters into adolescence, the time has come to critically engage with the continuing relevance of the "econophoric" outlook for Northeast Asian peace and security.

To this end, the rest of this article is as follows. After this short Introduction in Section I, in Section II I will briefly discuss selected aspects of the concept of "econophoria." As the basic idea is relatively straightforward, I restrict myself to: (a) highlighting aspects that are especially important for the case of Northeast Asia; (b) broaching a few of the concept's less intuitive aspects; and (c) introducing a few empirical and theoretical difficulties with the idea of "econophoria." In Section III, I evaluate the geo-economics and geo-politics of Northeast Asia through an "econophoric" lens. Of particular importance is the identification of the "Asian Paradox" as a situation that fundamentally calls into question the recent, stable status quo in the region. Finally, in Section IV, I conclude by arguing for why international institutions (especially regional international institutions) will be a crucial mechanism for continued stability, development, and peace in Northeast Asia going forward. In this way I hope to synthesize theory and empirical reality in a way that allows us to productively employ "econophoria" as a way of understanding the region, while also demonstrating that the actual, dynamic state of the region in some ways makes "econophoric" theory anachronistic, and thus that the concept itself requires transformation.

\section{THE THEORY OF "ECONOPHORIA"}

The theory underpinning optimistic excitement about economic growth, trade, and development as a primary driver of dyadic, regional, and even global peace is 
well understood (Kant 1795; Keohane and Nye 1977; Doyle 1986; Oneal and Russett 1999; Moravcsik 2003). Thus I will focus on only two factors. The first factor is assumed: namely, state behavior is rational (i.e., follows risk-weighted cost-benefit analysis) when there is a question of engaging in any action, including conflict. Second, the primary mechanism for "peace-through-trade-growth-anddevelopment" is interdependence, which is considered analytically to inhere in trade. Combined, these two factors are supposed to have several consequences that suffice to found cooperative relations among states:

(1) Interdependence makes some types of preparation for kinetic war challenging (Liberman 2000). For instance, the industrial base of a state whose economy is heavily intertwined with that of other states may be vulnerable to foreign and/or domestic investment curtailment, supply bottle-necks, or (in extreme cases) more or less targeted sanctions and embargos. And in any event interdependence makes preparation for conflict more transparent to other states and the international community, which can react appropriately. In its hyperbolic form, this is the idea of the famous Schuman declaration: that the European Community would make war in Europe "not only unthinkable, but materially impossible" (Schuman 1950).

(2) Both in present terms and in terms of the "shadow of the future," significantly improved state and population welfare (a function of specialization and comparative advantage utilized in trading) raises the risk-cost of a state starting war (Axelrod 1984; Mailath and Samuelson 2006). Conversely, improved welfare reduces the magnitude of economically aggrieved populations, who experience the benefits of international economic cooperation and are accordingly less likely to agitate for conflict (or be cynically manipulated into demanding it) as a pressure release.

(3) The "globalization" thesis: namely, international economic linkages weaken the state qua apparatus of power (at least relative to business interests), while citizenries become habituated to greater cosmopolitanism (Habermas 2001; Lee and Ju 2009). The first factor renders more difficult decisions to go to war because it implies a dilution of political power through an increased number of actors with access to decision-making levers; the second undermines "ingroup/out-group" psychology that undergirds popular support for war.

(4) Iterated cooperation in the economic domain can have knock-on effects (including trust-building) in other areas (Berg et al. 1995; Kurzban et al. 2006). In its "constructivist" version, this spillover effect promotes leadership political cultures in which the presumed inter-subjective atmosphere is more cooperative than conflictual.

The idea that economic interdependence leads to and preserves peace is 
prima faciae reasonable. On the theoretical side, it is clear how the aforementioned mechanisms can reduce state security risk factors by lowering levels of inter-state strategic mistrust. On the empirical side, it is simply the case that the post-WWII world has witnessed the simultaneous development of economic interdependence and remarkable peace (measured in many dimensions). Nonetheless, there are a number of theoretical problems and puzzles:

(a) One issue involves determining the correct unit of analysis: in the context of "econophoria," what does it mean to speak of "states" acting (e.g., to establish trade regimes), instead of leadership decision-making? This hoary question is relevant for all of IR, of course, but even more so for theoretical approaches whose putatively correlated objects of study (economic interdependence and peace) presume a diffusion of power to business groups and other actors, thereby undermining the idea of the unitary state (Bueno de Mesquita 2009).

(b) Another, related issue involves the assumption of "state behavior" as rational: quite beyond the question of what "state" behavior is, as opposed to the decisions of leadership coteries, there is a vast corpus of game theory literature devoted to explaining (both theoretically, and on an empirical basis) why ostensibly "economically rational" behavior produces sub-optimal (or even negative) outcomes (ibid).

(c) Moreover, to the extent that "econophoria" views economic interdependence as the overwhelming driver of peace that thwarts the ingrained nature of conflictual high-politics, "econophorists" may have put the cart before the horse: after all, interdependence does not happen in a vacuum, but rather requires legal action (sanctioned by appropriate state authorities) to facilitate it (at least at the start). In that case, political decision-making seems to be at least a coequal driver of peace, and perhaps even the ultimate driver (with interdependence a tool to that end).

(d) Indeed perhaps the correlation of economic interdependence and peace is causally spurious, subject to confounding variables. To take just one example, one might argue that the famed "democratic peace" (a concept related to, but analytically distinct from, economic interdependence) is the actual cause for pacific inter-state relations (Levy 1988; Goenner 2004; Kim and Rousseau 2005; Levy 2010). At the very least there is a methodological problem: it is difficult for IR models to disambiguate economic interdependence and tradebased economic development from democracy development (and therefore from democratic peace) precisely because so frequently the two arise concomitantly.

(e) What appears as interdependence may in fact be coerced trade preponderance of one trade partner over another. Although this might still technically fit the theory of interdependence and peace, the domination inherent in such a scenario is not in the liberal spirit that animates the idea. One forgets that trade can also 
form part of the constellation of high-politics, and thus may also be about interstate power.

(f) There is nothing that directly, inherently connects economic cooperation to peace - cooperation does not mean harmony (Keohane 2002). In fact, institutionalism emphasizes that rather the opposite is true, as cooperation presupposes differing interests, and therefore the potential for conflict (ibid). Policy practitioners even make no secret of the fact that in some cases trade deals are a weapon. For example, many analysts consider the Trans-Pacific Partnership (TPP) to be in significant part an effort to contain China, and US Defense Secretary Ashton Carter has referred to the nascent TPP as "as important to me as another aircraft carrier" (Japan Times 2015; Foreign Policy 2015; Carpenter 2015).

(g) There are empirical anomalies that undermine the theory also. Historically, the occurrence of WWI (among other examples) serves as a stern test for "econophorists." In the contemporary world, the advent of cyber-war is an obvious example (as are other forms of asymmetric warfare). I will return below to the WWI counterexample, but suffice it for the moment to point out that Europe was highly economically interdependent on July 27, 1914. As for cyber-war, it is a direct outgrowth of interdependence, and in this case the particular type of interdependence - namely, network interdependence - actually makes attack cheaper, easier, and less transparent/detectable (all of which are in contradistinction to (1) and (4) above).

\section{FROM "ECONOPHORIA" TO THE "ASIAN PARADOX"}

What does it mean, then, to refer to "econophoria" in the context of Northeast Asia? In the contemporary period, the idea starts with the acknowledgement that the region has much tinder for conflict (adversarial alliance structures, a destabilizing buffer state, a powerful revisionist state, historical grievances, territorial/ maritime disputes, etc.). Yet no state in the region has been in a sustained hot-war against another regional state for the last sixty-two years, and there is little reason to fear this imminently. Finally, the economic interdependence of China, Japan, South Korea, Taiwan, Mongolia, Russia, and the United States is deep, broad, and complex, which interdependence ${ }^{2}$ is considered by "econophorists" to be ipso facto the cause of regional peace (both in light of theoretical considerations, and because no superior reason suggests itself). So goes the argument, and obviously from this perspective Northeast Asia appears to be a case in which the development and security outcomes of economic interdependence warrant "econophoria."

Certainly, however, one can complicate this narrative by pointing out that it is only within the last 25 years that Northeast Asian economic interdependence has taken on a comprehensiveness and magnitude sufficient to explain a region-wide 
peace that has held for more than sixty years. Structural neorealists would therefore of course argue that balancing and Chinese-US-Russian/Soviet strategic deterrence account historically for much of Northeast Asia's regional peace, and that economic interdependence is at best an epiphenomenon (Waltz 1993; Kim 2005; Sorensen 2013).

Moreover the leadership of North Korea-which remains an active threat (and occasional kinetic aggressor) to South Korea in particular and the regional/ global community more generally - has mostly rejected calls for Chinese-style reform and opening up that would be pre-conditions for integrating more into the regional trade regime. ${ }^{3}$ On the one hand, one might argue that this strengthens support for the "econophoric" argument, in that the primary threat to peace in the region is the one state that has not become a part of the region's economic web. On the other hand, the fact that it has not means either: (a) the state is not acting rationally (a difficult proposition to sustain considering its continued survival in a difficult environment) and thus is outside the theory; or (b) the Pyongyang leadership does not undertake reforms because it is not in its interest as concerns remaining in power (this undermines the "econophoric" argument, however, insofar as its theoretical base assumes states, not leadership coteries, as the units of analysis); or (c) the economic interdependence prized by "econophorists" is not universally valid (this also undermines the "econophoric" argument, insofar as it considered a panacea).

In the final analysis, however, these first two complications to the "econophorist's" narrative are quibbles. Structural neorealists can indeed legitimately challenge the role of nascent economic interdependence in Northeast Asia's peace from 1953 to 1991. But what is good for the goose is good for the gander, and the onus is on structural neorealists to defend why their theory continues to explain said peace in a post-Cold War world (or at least explain it better than economic interdependence). In this world Northeast Asia is multi-polar and the globe is no longer bi-polar (both are conflict risk factors for structuralists), strategic nuclear deterrence is less important, and China has already risen to well within the zone of contestation vis-à-vis US regional pre-eminence (which would predict conflict, both for structural neorealists and power transition theorists). As for North Korea, it seems difficult to include its behavior in the checklist of counterarguments against economic interdependence as a driver of peace - in this case the exception tests all rules however, and indeed North Korea's sui generis behavior is similarly indigestible for other theoretical frameworks.

What is potentially more problematic for "econophorists" are two related states of affairs in Northeast Asia. The first can be designated the "WWI tinderbox argument": that is, as mentioned above, Northeast Asia resembles the economically interconnected Europe that nevertheless hurtled into WWI. This historical example is perhaps an outlier, and almost certainly an overwrought hobbyhorse ridden 
against "econophorists" general point. Nonetheless the similarities are present: historical and territorial issues, revisionism, multi-lateral alliances, nationalism, etc. ${ }^{4}$ One can effectively discount these challenges by counter-arguing: (a) that they are little more than coincident facticities embedded in a regional structure that is very different from pre-1914 Europe, and (b) today's leaders have at their disposal the experience of WWI as prophylaxis. ${ }^{5}$ Rather, I think, the truth in, and danger of, the idea of contemporary Northeast Asia as pre-WWI Europe is that Northeast Asian nation-states have a comparatively weak liberalism, like in pre-WWI Europe, as measured by democratization, civil society, civil liberties, multi-culturalism, free media, and economic marketization. This weakness is true both in tradition and current practice, and of course some Northeast Asian nation-states are much more liberal than others. It is especially conspicuous that China, the region's major economic and security player, is not only completely illiberal, but seemingly retrenching rather than progressing. This is a problem for "econophorists" argument because the development of liberal values concomitant to economic interdependence is one part of the supposed peace mechanism (indeed one of the major arguments to explain WWI as an outlier vis-à-vis the "peace-through-economicinterdependence" argument is that Prussia, in particular, was illiberal both in tradition and practice).

The second, related real problem for "econophorists" can be summed up with the shibboleth "Asian Paradox," a termed used by theorists and practitioners alike (including Korean President Park Geun Hye). This refers to the fact that in recent decades Northeast Asia has seen explosive growth and development, massively increased regional trade, overall deeper and broader economic interdependence, and greater exchanges of all types (including human exchanges), and yet this has not lowered strategic mistrust among the region's actors. The most visible sign of tensions is Chinese and Japanese maritime saber-rattling, Japanese constitutional revision and reinterpretation, China's declared ADIZ in the East China Sea, and US-Japan-Chinese confrontations in the South China Sea. From a theoretical perspective, what is important is that economic interdependence as a driver of peace is not static, but is rather a dynamic mechanism: this means that increased economic interdependence should track increased political/security cooperation and trust (and the converse). The fact that this has not happened-that regional political cooperation is poor, and comprehensive collective security arrangements nonexistent - is a challenge both to theorists and practitioners.

\section{IV. "ECONOPHORIA'S” LIMITS, INTERNATIONAL INSTITUTIONS, AND THE NEED FOR STATESMANSHIP IN NORTHEAST ASIA}

Problems and puzzles notwithstanding, Northeast Asia's relative peace is as explicable by economic interdependence as by competing theories. The year 2015 
illustrates the point, as the saber-rattling between China and Japan was calmed and stabilized in significant part due to both sides' realization of the role of Japan's 20,000 businesses operating in China (employing millions of Chinese, serving as a source of crucial technology transfer, allowing Japanese firms to remain profitable), and the fact that Japanese industry needs Chinese rare-earth metals. Also in 2015 South Korea and China experienced a second honeymoon of economic and political cooperation, South Korea and Japan agreed to defuse tensions via a bilateral Park-Abe summit they had studiously avoided for several years, and a China-Japan-South Korea trilateral summit took place in November. The major lesson, in any event, is that for the moment economic integration in the region seems to be the privileged path to the creation of an improved security environment: this ranges from bi-lateral FTAs, to the multi-lateral Eurasia Initiative, to oil/gas pipeline connections, to natural resource trade (including that involving North Korea), among other schemes.

That said, many of the aforementioned generalized problems with the theory of "peace-through-economic-interdependence" are displayed in the empirical case of Northeast Asia. Hence the notion of the "Asian Paradox" as a state of affairs that covers up conflict risk factors. In the case of Northeast Asia, the "Asian Paradox" expresses the fact that the aforementioned generalized theoretical problems (b), (c), and (f) impinge on aforementioned causal factor (4) connecting economic interdependence to peace. That is to say, first, in terms of (b), that a component of the security risks adumbrated in the idea of the "Asian Paradox" is that Northeast Asian state leaders may have been, in the game-theoretic sense, playing noncooperative games (or, at the least, competing without complete and perfect information). Second, in terms of (c), Northeast Asian leaders may have, for a long time, relied too much on political and security architecture put in place during the Cold War (security guarantees, multi-lateral institutions, etc.), architecture that provided nucleation sites for growing regional economic interdependence and peace maintenance, but that also masked the need for leaders to understand the difficult work of maintaining that architecture through inter-state political compromise. This last point amounts to the same thing as (f) above, namely that the leaders in question erroneously have acted as though economic cooperation will result in harmony. The result has been the lack of internalization of "trustbuilding" as a spillover effect of economic interdependence, and thus a paucity of shared, available political tools to deal with both security challenges and the negative side of globalization itself (which instead is frequently sublimated into nationalist sentiment).

It is especially through this lens of globalization that the "Asian Paradox" reveals the truth and limits of "econophoria": namely that its truth is limited temporally and logically. The half of the "Asian Paradox" that references strategic and security mistrust belongs to the era of the nation-state (a polity mandated to 
maximize citizen welfare and public goods); the half of the "Asian Paradox" that encompasses contemporary economic interdependence (dyadically, regionally, and globally) belongs to what Philip Bobbitt has called the "market-state" (a polity mandated to maximize consumer choice, optimize trans-national capital allocation, and provide a maximally conducive environment for multi-national business networks)(Bobbitt 2003, 228-229). ${ }^{6}$

Temporally the current Northeast Asian ${ }^{7}$ status quo- "economic interdependence equating to peace"-persists uneasily on the cusp of this epochal, yet ephemeral overlap of the nation-state and "market-state." This is the deep, historical structure underlying the "Asian Paradox." We are now in a transition phase marking the end of the nation-state epoch and the advent of the dominance of the "market-state." As that transition continues inexorably, the peace side of the equation will change as the character of economic relations changes.

Logically the limit of equating economic interdependence and peace is found in the transition from nation-state to "market-state" dominance, a transition that has been catalyzed by a globalization the seeds of which were contained within the nation-state itself (Habermas 2001; Bobbitt 2003). That is, the nation-state's solution to the exigency of creating both economic success (including interdependence $^{8}$ as a precondition) and strategic security - and therefore, especially, postWWII peace - rested on revolutions in automated calculation speed and power (a condition for global/regional trade and logistics), communications (a condition for global/regional trade and logistics), and weapons of mass destruction (more specifically nuclear weapons, a condition for the deterrence that allowed the Cold War to remain cold) (Bobbitt 2003). ${ }^{9}$ The revolutions in computation and communication are, in fact, not only the core of the nation-state's politico-economic character, but also the foundation for economic globalization that escapes the channeling capacity of the nation-state (if not the state as such), and in so doing forces its adaptation to systemically generated market choices and thus metamorphosis into the "market-state." As this transition is ongoing, some parts of the state are more advanced down this path than others, and in the case of Northeast Asia the "Asian Paradox" expresses itself in globalized, "market-state" economic networks coupled to strategic security arrangements (territoriality, balance of power, spheres of influence, defensive alliances) and mentalities (e.g., nationalism ${ }^{10}$ ) that are relics of the nation-state (or even of earlier state forms). As the "market-state" grows and progresses implacably (cycling from growth to crisis) while the nationstate hollows out (withers away, dries up, and is obliterated by the winds of history), the connection of economic interdependence to peace will come into question, especially (but not only) in Northeast Asia. This is because no one knows (a) how the economic relations of the "market-state" will fare, and (b) what politicosecurity arrangements and mentalities will evolve concomitantly to it (a necessity since those of the nation-state will be superseded). Optimistic analyses emphasize 
how optimized capital allocation and bootstrapped technological gains will accelerate absolute improvements in living standards and economic opportunity in general. Pessimistic analyses point out that the problem with the "market-state" is that it awakens universal consumer desires precisely at a time when it is less capable of fulfilling them for everyone, and that this will lead to a seething and potentially volatile (and violent) global underclass.

If the foregoing analysis is correct, then the central question for "econophorists" (both in Northeast Asia and beyond) must be: "what are the political forms of the post-nation-state world that will be adequate to (can compete with) both the power and fluidity of the economic networks linking 'market-states,' and to the security challenges that might threaten to break out into war?" Insofar as these political forms should be democratic, they will inherit something of the nation-state (representativeness, accountability, etc.). These political forms will also inherit another principle from the nation-state: as mentioned, peace-even an economically constructed peace-does not arrive in a vacuum. A cursory examination of domestic peace finds its economic roots in the function of politics: namely, contracts (the basis of the domestic free market's trade in goods and services) require political infrastructure (public goods to make production-distribution-consumption possible, contract enforcement mechanisms, etc.) heretofore provided by the state (and, as will be discussed below, also by international institutions). Indeed, the same principle that works for domestic peace through state structured political foundations is at work in inter-state peace derived from international economic interdependence. The crucial trade component does not come about automatically, ${ }^{11}$ but rather also requires political infrastructure, some of which is national (FTA negotiating teams, government-backed commercial banking and financial support services, credit guarantees, Exim banking, monetary policy and facilities, etc.) and some of which is transnational (trade organization secretariats, international governance of payment/settlement systems, independent dispute settlement arbitrators, etc.). In a post-nation-state world these roles will be increasingly — but not totally — taken by international institutions with more or less democratic accountability.

At the twilight of the nation-state in a peaceful and prosperous Northeast Asia, we must not give up on the role of the state, or politics more generally, as "econophorists" might have it: rather the opposite is true, as we now need the leaders of China, South Korea, Japan, the US, Taiwan, Russia, and Mongolia to be statesmen/stateswomen, and take advantage of good economic conditions to make difficult (even unpopular) choices to create powerful and legitimate post-nationstate institutions that will be adequate to the future economic and security challenges posed by a globe and region formed by the "market-state." The economic international institutions would be mechanisms through whose architecture interdependent trade of our globalized world would not merely flow, but be in fact 
channeled. Perhaps, in this way, and if these economic relations bind and create transnational solidarity as a foundation for continued peace, the "econophorist" logic can be salvaged from the nation-state on a higher political level. And perhaps such international institutions need not, for their contribution to peace, be limited to economic matters from the very beginning, if there is low-hanging fruit in other domains in Northeast Asia (human security, public health, etc.). In any event the region has a paucity of all of these kinds of institutions (another expression of the "Asian Paradox"), and the ones that do exist are only as good as the spotty leaderships who back their design and uphold their functionality.

I conclude by reviewing the theoretical and empirical arguments for why international institutions represent a successor to "econophoria." In the first place, it is useful to understand the theoretical role of international institutions for the question at hand: "what are the political forms of the post-nation-state world that will be adequate to (can compete with) both the power and fluidity of the economic networks linking "market-states," and to security challenges that might threaten to break out into war?" These theoretical roles range from trust-building through iterated cooperation to incentivizing rules-following to lowering transaction costs. All are important, but the latter deserves special focus, because it is highly organically connected to the very nature of the "market-state" to which it should be a partial answer. Indeed, the international institution literature acknowledges that to a great extent our understanding of international institutions is indebted to economist Ronald Coase's theory of the firm (the dominant socio-political and economic organization of the end of the nation-state era and the advent of the "market-state"). Specifically, Coase's theory-for which, in part, he later won the Sveriges Riksbank Prize in Economic Sciences in Memory of Alfred Nobelstarts with the observation that firm size tends to grow beyond the magnitude that models can account for through economies of scale, and concludes by demonstrating that unmanageable and inefficient transaction costs lead firms to internalize production (and other aspects of business) rather than contracting for them in a marketplace (Coase 1937). Pioneering researchers such as Keohane (1982, 2002), Abbott and Snidal (1998), and Stein (2008) appropriated the general argument that hierarchy is sometimes superior to market-based transactions, and showed that international institutions can accomplish the same transaction cost reduction (concerning political deals) for states that the firm can in the business world. For example, it is difficult to negotiate and manage a 10-party multi-lateral FTA, but it is essentially impossible (or at least impossibly time-consuming) for each of the ten parties to individually negotiate bi-lateral FTAs with each of the other nine parties. The same holds true, mutatis mutandis, for agreements dedicated to other domains of cooperation as well (e.g., state security, human security, cybersecurity, ${ }^{12}$ etc.). In any event, in a world in which risks (economic or otherwise) tendentially use the arbitrage networks and pathways of globalization to escape the 
control of states, international institutions represent a functional political response.

In the second place, theories of international institutions observe their flexibility, their opportunism, in approaching challenges. As the literature shows, there are two ways of imagining the formation of cooperation. One way first assumes trust, which allows for cooperation (even on major deals); the other argues that cooperation can function to create trust, leading in turn to greater cooperation (and a furthering of the virtuous circle). In the case of Northeast Asia, of course, strategic mistrust is comparatively high; in fact, even the prospect of regional economic integration is dim. Thus the former approach — one that produces grand bargainsis highly unlikely, and it is in fact the latter approach that analysis informs us is appropriate to the current situation. The key to the latter approach, however, is that leaders must choose the right type of "Goldilocks" issue as a "nucleation site": it cannot be too frivolous, as it would seem insignificant, but neither can it be too important, as lack of trust would impede meaningful commitments. International institutions are appropriate venues for such a process, as they facilitate information exchange, build in some (even if only marginal) level of enforcement, and allow for multiple areas and iterations of cooperation. ${ }^{13}$

In the third place (which is connected directly to the aforementioned argument for starting with small cooperation and then moving up the chain of significance), there remains the question of what specific proposals and measures make sense in Northeast Asia, and what kind of leaders can execute them. With respect to global issues, Northeast Asia has recently found success (or is succeeding) on a surprising number of major initiatives: the TPP, the Asia Infrastructure and Investment Bank (AIIB), the KORUS FTA, Framework Agreements with the EU (even including security cooperation), carbon market linking, and even ROK-Japan-China collaboration fighting piracy in the UN Mission off the coast of Somalia. Regionally, however, as aforementioned, the record is poor for major economic and security initiatives (RCEP notwithstanding), either due to a lack of imagination or a lack of leadership support and execution: the disappointments of the Eurasia Initiative, the Northeast Asia Peace and Cooperation Initiative (NAPCI), and the Trilateral Cooperation Secretariat (TCS) are just a few examples.

Given all of this, it seems reasonable to counsel institutional cooperation (especially on a regional, multi-lateral level) that is vigorously supported by governments and their leaders. There is a lot of low-hanging fruit to be gathered here, which could in turn catalyze improved economic and security governance. Examples include: public health cooperation (for pandemic disease prevention), environmental security (notably for air pollution mitigation), technical nuclear safety, and deconfliction (at a minimum) and possibly collaboration between the AIIB and Asia Development Bank (ADB).

This will require statesmanship. Certainly "econophorists" may scoff at the idea of such political leadership, and it does in fact seem anachronistic. But the 
statesmanship referred to here is not the statesmanship of grand bargains over epoch-defining Gordian knots. As of the writing of this article (2015) the world is busy celebrating the $200^{\text {th }}$ anniversary of the Congress of Vienna and the $800^{\text {th }}$ anniversary of the Magna Carta - but such world-historical breakthroughs are not the order of the day. Rather the opposite is the case: currently we require the statesmanship of restraint, of a solid vision of the manageable near-future rather than the fever dream of castles in the air. Call this the statesmanship of the Serenity Prayer: Lord, grant our leaders the courage and strength to change the things they can (even if only marginal, feasible things, rather than flashy vote-getters), the patience and serenity to accept the things they cannot, and the wisdom to know the difference. May we all hope that such statesmen are not as rare as unicorns.

\section{REFERENCES}

Abbott, Kenneth and Duncan Snidal. 1998. "Why States Act Through Formal International Organizations." The Journal of Conflict Resolution (42)1: 3-32.

Axelrod, Robert. 1984. The Evolution of Cooperation. New York: Basic Books.

Berg, Joyce, John Dickhaut, and Kevin McCabe. 1995. "Trust, Reciprocity, and Social History." Games and Economic Behavior (10)1: 122-142.

Bloomberg, Business. 2014. Abe Comparing China Ties to Pre-War Europe Fuels Tensions, in Bloomberg Business, January 24, 2014, accessed October 11, 2015, http:// www.bloomberg.com/news/articles/2014-01-23/abe-comparingchina-to-pre-world-war-one-germany-fuels-tensions

Bobbitt, Phillip. 2003. The Shield of Achilles: War, Peace, and the Course of History. New York: Anchor Books.

Bueno de Mesquita, Bruce. 2009. Principles of International Politics. New York: CQ Press.

Buzan, Barry and Gerald Segal. 1998. "Rethinking East Asian Security." World Security: Challenges for a New Century, edited by Michael T. Klare and Yogesh Chandrani. New York: St. Martin's Press.

Carpenter, Ted Galen. 2015. The Trans-Pacific Partnership: Washington's Unwise Exclusion of China, in Cato Institute Commentary, October 10, 2015, accessed October 26, 2015, http://www.cato.org/publications/commentary/transpacific-partnership-washingtons-unwise-exclusion-china

Coase, Ronald. 1937. "The Nature of the Firm." Economica (4)16: 386-405.

Doyle, Michael. 1986. "Liberalism and World Politics." American Political Science Review (80): 1151-1169.

Foreign, Policy. 2015. What Will the TPP Mean for China? Foreign Policy, October 7, 2015, accessed November 2, 2015, http://foreignpolicy.com/2015/10/ 07/china-tpp-trans-pacific-partnership-obama-us-trade-xi/

Goenner, Cullen. 2004. "Uncertainty of the Liberal Peace." Journal of Peace Rese- 
$\operatorname{arch}(41) 5:$ 589-605.

Habermas, Juergen. 2001. "The Postnational Constellation." The Postnational Constellation: Political Essays, edited by Max Pensky. Boston: MIT Press.

Japan, Times. 2015. TPP Deal as Important as New Aircraft Carrier: Pentagon Chief, in Japan Times, April 7, 2015, accessed November 2, 2015, http://www.japan times.co.jp/ news/2015/04/07/business/tpp-deal-important-new-aircraft-carri er-pentagon-chief/\#.Vi5z5xXn_cs

Kant, Immanuel. 1983. "Perpetual Peace.” Perpetual Peace and Other Essays. New York: Hackett.

Keohane, Robert. 1982. "The Demand for International Regimes." International Organization (36)2: 325-355.

Keohane, Robert. 2002. Power and Governance in a Partially Globalized World. New York: Routledge.

Keohane, Robert and Joseph Nye. 1977. Power and Interdependence: World Politics in Transition. Boston: Little, Brown.

Kim, Jangho. 2005. "Back to Basics: Multi-lateral Security Cooperation in Northeast Asia and the Neorealist Paradigm." The Korean Journal of International Relations (45)5: 37-56.

Kim, Hyung Min and David Rousseau. 2005. "The Classical Liberals Were Half Right (or Half Wrong): New Tests of the Liberal Peace (1960-1988)." Journal of Peace Research (42)5: 523-543.

Kurzban, Robert, Mary Rigdon, and Bart Wilson. 2007. "Incremental Approaches to Establishing Trust." Experimental Economics (11): 370-389.

Lee, Jong Wha and Ju Hyun Pyun. 2009. Does Trade Integration Contribute to Peace? ADB Working Paper Series on Regional Economic Integration (24), accessed November 4, 2015, https://aric.adb.org/pdf/workingpaper/WP24_D oes_Trade_Integration.pdf

Levy, Gilat and Ronny Razin. 2004. "It Takes Two: An Explanation for the Democratic Peace." Journal of the European Economic Association (2)1: 1-29.

Levy, Jack. 1988. "Domestic Politics and War." The Journal of Interdisciplinary History (18)4: 653-673.

Liberman, Peter. 2000. "The Offense-Defense Balance, Interdependence, and War." Security Studies (9)1/2: 59-91.

Oneal, John and Bruce Russett. 1999. "The Kantian Peace: The Pacific Benefits of Democracy, Interdependence, and International Organizations (1885-1992)." World Politics (52)1: 1-37.

Mailath, George and Larry Samuelson. 2006. Repeated Games and Reputations: Long-run Relationships. Oxford: Oxford University Press.

Moravcsik, Andrew. 2003. "Liberal International Relations Theory: A Scientific Assessment." Progress in International Relations Theory: Appraising the Field, edited by C. Elman and M.F. Elman. Boston: MIT Press. 
Schuman, Robert. 1950. Schuman Declaration, accessed October 31, 2015, http://e uropa.eu/about-eu/basic-information/symbols/europe-day/schuman-declarati on/ind ex_en.htm

Sorensen, Camilla. 2013. "Security Multilateralism in Northeast Asia: A Lost Game or the Only Way to Stability?" Journal of China and International Relations (1) $1: 1-25$.

Stein, Arthur. 2008. "Neoliberal Institutionalism." The Oxford Handbook of International Relations, edited by C. Reus-Smit and D. Snidal. Oxford: Oxford University Press.

Van Evera, Stephen. 1986. "Why Cooperation Failed in 1914." Cooperation Under Anarchy, edited by K.A. Oye. Princeton, NJ: Princeton University Press.

Waltz, Kenneth. 1993. "The Emerging Structure of International Politics." International Security (18)2: 44-79. 


\section{ENDNOTES}

1 I count the U.S. as a Northeast Asian regional country, given its large economic, diplomatic, and (above all) military role in the region.

2 This "econophoric" presumption not only is held with respect to regional economic interdependence, but also to the global "real" economy (i.e., including trade in goods, commodities, and services, but bracketing out global financial market activity, largely due to the 1997 Asian financial crisis, which seriously impacted Northeast Asia in general and South Korea and Taiwan in particular). Just as an example, since 2011 the U.S. boom in unconventional hydrocarbon production (especially hydraulic fracturing) has permitted major declines in oil prices (from >100USD per barrel in 2013 to < 50USD per barrel in 2015) despite a horrendous ongoing conflagration in the Middle East, which historically would have led to sharp price spikes (also for natural gas, whose price is typically linked to oil). As most Northeast Asian states are highly dependent on oil/gas imports, they have benefitted enormously from the global hydrocarbon commodities market-in fact, there is a high probability that Japan and South Korea would be in recession (and the Northeast Asian region as a whole more volatile) were it not for the energy production glut that has driven down their import costs.

3 This remains the case despite the existence of Special Economic Zones, the Kaesong Industrial Complex, the Pyongyang regime's opaque trade with China, and illicit trade.

4 Stephen Van Evera $(1986,80)$ argues that the following principal factors (among others) led to WWI: "European states adopted expansionist policies that fostered territorial conflict, engaged in arms races with one another, developed mobilization plans whose scope and inflexibility made crises hard to control and wars hard to localize ..." Without exaggerating, one can argue that some form of all three of these elements is present in Northeast Asia.

5 Indeed Shinzo Abe (Bloomberg Business 2014) has already explicitly made this point (although ironically his comments irritated other East Asian leaders).

${ }^{6}$ Bobbitt defines the "market-state" thusly: "The market-state is a constitutional adaptation to the end of the Long War and the revolutions in computation, communications, and weapons of mass destructtion that brought about that end... Such a state depends on the international capital markets and, to a lesser degree, on the modern multi-national business network to create stability in the world economy, in preference to management by national or transnational political bodies. Its political institutions are less representative (although in some ways more democratic) than those of the nation-state."

7 It should be noted that the same can be said of the European Union, another prime example of the equation of economic interdependence with peace.

8 Although notably, of course, not between the Western countries and their Warsaw Pact ideological adversaries.

9 In fact, the revolutions in communications and weapons of mass destruction presupposed the computation revolution (the ur-revolution of the nation-state). Although various analog and electromechanical computers (including those used by the US Navy for trigonometric torpedo targeting during WWII) were in use from the late 1920s until the early 1940s, it was the invention and operationalization of vacuum tubes and digital electronic circuits that truly laid the foundation for the revolution in calculating power and speed that made globalization possible. One would be remiss, however, if one failed to point out that vacuum tubes and digitization were not born of the civilian ether: they were both intentionally developed for military use, namely breaking German military encryption and developing the hydrogen bomb.

${ }^{10}$ One can argue that the increase in nationalism/provincialism in EU countries in recent years is a retrenchment of the nation-state mentality in the face of a relentless "market-state" advance even in a time of crisis.

${ }^{11}$ Free trade is a fiction. "Free" trade deals are massively complex documents of thousands of tediously negotiated tariff schedules, rules, and regulations. They are the expression of difficult choices (trade-offs) that create both winners and losers, and must be transposed into domestic law. As such these deals are in need of political leadership (this is true of bi-lateral trade, and especially true of multi-lateral deals).

${ }^{12}$ Other than perhaps global greenhouse gas emissions, no other security area is so in need of international institutional cooperation as cyber-security. The fact that the forces of globalization make cyber-attacks cheaper, easier, and less transparent/detectable is problematic enough, but, moreover, offensive capabilities outstrip defenses, offensive cyber-war can be asymmetric, and the potential effects of attack are potentially both widespread and devastating (electrical grid outages, transportation infrastructure destruction, etc.).

${ }^{13}$ It also worth noting that international institutions are venues for two-level games, which also increase their efficacy. 